\title{
Designing an Arabic Speaking and Listening Skills E- Course: Resources, Activities and Students' Perceptions
}

\author{
Tawffeek Mohammed \\ University of the Western Cape, South Africa \\ tawffeek@gmail.com
}

\begin{abstract}
This paper presents a fully online course model for teaching speaking and listening skills for students learning Arabic as a foreign language at the International Peace College South Africa on the NEO learning management platform. It also investigates the students' attitudes towards the course. The course was developed by the researcher during the first semester of 2020. This period coincided with South Africa's first wave of COVID-19, and the country's first strict lockdown. The syllabus consists of three components: listening, speaking and conversational Arabic. It includes various technologyenhanced activities and resources which were developed by using LMS features, Web 2.0 tools, and e-learning specifications such as Learning Tools Interoperability (LTI) and Shareable Content Object Reference Model (SCORM). The integration of technology in the course is based on an approach that combines Bloom's taxonomy and Technology Integration Matrix (TIM). Apart from the description of the course, this study used a thirty-item questionnaire to investigate the attitudes of thirtyone learners who participated in the course. They answered questions about the course's resources, activities as well as its impact on their language skills. Results from the questionnaire revealed that the respondents' attitudes towards the online course were positive and statistically significant at $p<.05$. The design and the approach adopted in this study can apply to any context of language teaching. It provides a myriad of technology-enhanced activities that can be effectively used to teach listening and speaking skills virtually. Foreign language teachers can adopt this approach in its entirety, or with idiosyncratic modifications to design their language courses, irrespective of the virtual learning ecology (VLE) they use.
\end{abstract}

Keywords: Technology-enhanced, AFL, Speaking, Listening, Fully online, NEO, Learning Management System (LMS)

\section{Introduction}

Since the outbreak of COVID-19 in 2019, lockdown was considered by the South African government to be the safest solution to curb the spread of the virus no matter the repercussions. For instance, lockdown orders due to COVID-19 have necessitated the need to transition to remote learning, especially since social distancing has become a priority as the world battles this virus. Educational institutions have started to find ways to bring their entire workflow into contact-free systems. Hence, remote learning is no longer a matter of choice; and all stakeholders need to work hard to achieve this goal (Ali, 2020; Ferri, Grifoni and Guzzo, 2020; van Cappelle et al., 2021). Many educators have been grateful to e-learning companies that put aside profitability during the pandemic to assist them in transitioning to e-learning. Providers of learning management systems such as Moodle, Cypher Learning, and Canvas raced to offer their software to schools around the world for free. Undoubtedly, these applications help educational institutions to deliver their content, but there are wider implications (Al Rawashdeh et al., 2021). While the valuable benefits of remote learning in such unprecedented circumstances are apparent, shifting education from a traditional classroom setting into a digital modality may not always be as simple as e-learning providers often claim. Problems arise not only in implementing a digital platform for content delivery, but also when addressing infrastructure, the digital literacy of students, instructors, and administrative staff; instructional design, and data access (Mpungose, 2020; Rapanta et al., 2020). The challenges related to abrupt transitions to online learning may differ across institutions, subjects, and modules.

The present study therefore focuses on the design of a fully online course for teaching Arabic as a foreign language at an institution of higher learning in the South African context. The design of fully online or blended modules is without a doubt exceedingly beneficial to foreign language learners in general. This is partly dictated by the fact that teaching a foreign language in a traditional environment can hardly equip the language learner with the necessary skills needed to develop linguistic competence. Learners need time to practice outside of the classroom. At the same time, controlled, engaging online materials certainly play a vital role in enhancing the language skills of students. The fact remains that online learning materials should not be implemented haphazardly (Ghani and Daud, 2018). 


\section{Statement of the Problem}

When the first confirmed case of COVID-19 was reported in South Africa in March 2020, the country imposed strict quarantine and lockdown measures. The International Peace College South Africa, like all other tertiary institutions in the country, found itself in a scenario where emergency remote teaching was required. The restrictions have had a profound impact on the teaching of some Arabic language modules, especially ones that require more intensive cognitive abilities on the part of the learners, such as listening and speaking. The teaching of these skills requires the use of various effective activities in the classroom that cannot always be sufficiently replicated in synchronous Zoom sessions. Even in a traditional face-to-face classroom, a listening and speaking course centers on the use of conversations, simulations, debates, discussions, and multimedia activities that are normally conducted in a physical multimedia lab. Remote teaching and learning of language courses therefore need to consider how to replicate or replace such activities. Remote instruction should also utilize technology that ensures adequate use of appropriate language teaching methodologies, such as the communicative approach. Given that many teachers and learners are digitally literate necessitates instructional designers to create learning prototypes that incorporate adequate activities, resources, and teaching methodology. Presently, there is no formal syllabus for teaching Arabic as a foreign language at IPSA or at other South African institutions. The selection of the materials is at the discretion of the instructor, and materials may differ from year to year. The Arabiyyah Bayna Yadayk [Arabic between your hands] series is commonly used by some instructors for teaching Arabic modules. However, those textbooks are more suitable for students at the elementary and intermediate levels, not for university students, who need to meet the requirements of National Qualifications Framework (NQF) levels 5, 6 and 7 in terms of competencies and skills.

The present study is therefore action-based research that attempts to design a learning prototype that can be used either fully online, or in a hybrid mode, especially in countries that, notwithstanding exceptional circumstances brought about by the COVID-19 pandemic, encounter intermittent problems such as natural disasters, protests, violence, and so on. This study not only aims to describe the designed listening and speaking e-course, but it also examines the perceptions of the students towards course resources and activities. Due to the exploratory nature of this study, research questions rather than hypotheses were investigated. The questions used to guide the study are:

1. What are the attitudes of the AFL learners towards the resources of the designed e-course?

2. What are the attitudes of the AFL learners towards the activities of the designed e-course?

The perceptions of other stakeholders are equally important, but are beyond the scope of this study.

\section{Literature Review}

Online learning, whether hybrid or totally remote, has attracted the attention of language learners and educators. This interest has resulted in a bulk of literature in certain areas of language pedagogy. The use of disruptive technologies in teaching foreign languages was, for instance, investigated in several studies. Some of these studies investigated the use of social media platforms (e.g., Facebook and WhatsApp), Wikis, YouTubebased materials, and other multimedia for teaching Arabic vocabulary and writing skills (Abdullah, 2015; Wargadinata et al., 2020; Zainuddin and Sahrir, 2016; Albantani and Madkur, 2017). Other studies dealt with the use of Web 2.0 tools for enhancing reading and writing skills (Shalihah et al., 2021), the role they play in the achievement of learners (Mohammed, Assam and Saidi, 2020), and the use of websites for the delivery of content (Ghani and Daud, 2018). The attitudes of students and teachers towards the use of social media platforms and Web 2.0 tools in the Arabic language classroom were also explored (Bahruddin and Febriani, 2020; Wargadinata et al., 2020; Abdullah, 2015).

The use of such tools mentioned above will not yield the desired results if they are not aligned with the learning outcomes of a course. While the use of technology in teaching a foreign language is undisputable, adequate attention has not been paid to the design of syllabi or learning prototypes that can enhance the language skills of learners. A few studies have dealt with the use of learning management systems in some foreign language courses which used a blended or hybrid mode of teaching. Moodle, for instance, has been used for the delivery of an online component for teaching English lexical and grammatical topics in a blended English language course for Spanish-speakers with a focus on writing skills (Rymanova, Baryshnikov and Grishaeva, 2015). Moodle was also used for the teaching of business English at a Czech University (Kučírková, Kučera and Vydrová, 2014). Similarly, Google Classroom was used to teach postgraduate courses on communicative English grammar (Haggag, 2019) and English business writing skills (Apriyanti et al., 2019). The perceptions of students at a 
Bangladeshi university towards using Google Classroom for teaching English were also investigated (Islam, 2019). Another study reported on the use of LMS in teaching learners with existing knowledge of English at a Russian university with the aim of individualizing language learning (i.e., tailoring the course to fit the needs of individual learners). This study underscored the importance of adopting multiple learning paths that integrate various learning styles (Tumskiy, 2019). Another recent study investigated the use of Canvas LMS for the delivery of content in the form of e-books for Arabic language learning in an Indonesian context (Fauzi et al., 2020). While the above studies agree that there is a strong correlation between the use of learning management systems and student achievement, the findings are largely based on summative achievement tests that may or may not reflect the true abilities of learners.

Among the four language skills, speaking and listening received less attention in the existing literature than reading and writing. Some studies reported on the impact of blended learning activities on the augmentation of English listening and speaking skills in the Bangladeshi, Indonesian and Omani contexts (Rabbi, Zakaria and Tonmoy, 2017 ; Rahmawati, 2019; Pramila and Thomas 2019 ; Hussein Alsowayegh et al., 2019 ; Grgurovic 2011). Those studies employed various learning management platforms such as Google Classroom, the online Cambridge LMS, and Blackboard ${ }^{\circledast}$.

Although the above studies emphasize the use of technology in foreign language teaching and learning, they focus on the general benefits of technology. They also largely focus on the perceptions of learners towards the mode in which learning content is delivered, their dedication and acceptance of technology, and the optimization of teaching hours. These studies do not, however, describe the learning prototypes used in content delivery, how technology has been integrated, or the impact of course design on student language skills. In addition, the studies are generally concerned with hybrid or blended learning, which implies that higher-order thinking activities are used in a traditional classroom. In most of the above studies, "technology integration seems to be an isolated goal to be achieved separately from pedagogical goals" (Ertmer and Ottenbreit-Leftwich, 2013, p.176). The haphazardness of many online designs and their failure to reach their full potential could be attributed to lack of emphasis on pedagogical underpinnings such as Bloom's taxonomy, and on technologyintegration models such as SAMAR, TIM, ADDIE, ASSURE, and etcetera. Very few studies reported on online language instructional designs based on such integrative models (Yugandhar, 2016; Aljojo et al., 2019; Mohammed, Assam and Saidi, 2020).

Hence, this study differs from the previous ones in several aspects. Firstly, it is an extension of other empirical studies that attempted to integrate technology in the teaching of Arabic as a foreign language (Mohammed, 2018; Mohammed, Assam and Saidi, 2020; Mohammed, Al-Sowaidi and Banda, 2021). Unlike other studies, the present study aims to design course content for the teaching of speaking and listening skills which have been described as highly demanding, complicated and multi-faceted (Asakereh and Dehghannezhad, 2015; Walker, 2014). Listening skills in particular are often marginalized in the language syllabi and have commonly been "regarded as a passive skill, [...] an ability that would develop without assistance" (Osada 2004, p.53). To master these two skills, instructional designs need to equip learners with sufficient knowledge of vocabulary, grammar, culture, genre, speech acts, register, discourse, and phonology (Scrivener, 2005). This requires the design of highly motivating materials that can be used for the teaching of listening and speaking skills in a fully online or hybrid environment. Although LMSs play a vital role in the delivery of materials and the management of learning, relying on the features of a particular LMS may be insufficient for a productive teaching and learning experience. In other words, LMSs are designed to serve education in general, and may not include diverse tools for listening and speaking activities. Therefore, the learning prototype described in this study makes use of various webbased tools and e-learning standards such as SCORM. The use of such standards does not only assist in the design of learning activities, but also in the offline delivery of materials. This is the first known study that integrates technology into the teaching of Arabic speaking and listening skills based on modern pedagogical and technology-enhanced instructional approaches. Technology alone is not sufficient for ensuring an ideal online learning environment. Successful instructional design needs to strike a balance between pedagogy and technology (Garrison and Norman, 2008; Harasim, 2017; van Merriënboer and Paul, 2017; Picciano, 2017). This study, therefore, adopts a focused approach to the integration of technology, which is described in the following section. 


\section{Theoretical and Conceptual Framework}

This study is based on an eclectic approach that integrates concepts from information technology and instructional design. In particular, it utilizes Bloom's taxonomy of learning objectives (Bloom, 1956) and the Technology Integration Matrix (TIM) (Technology Integration Matrix, 2009; Hornack, 2011; Welsh, Harmes, and Winkelman, 2011). Bloom's taxnomoy is composed of six levels that can be used to structure the learning objectives, lessons, and assessments for any course. Those levels are shown in Figure 1 below.

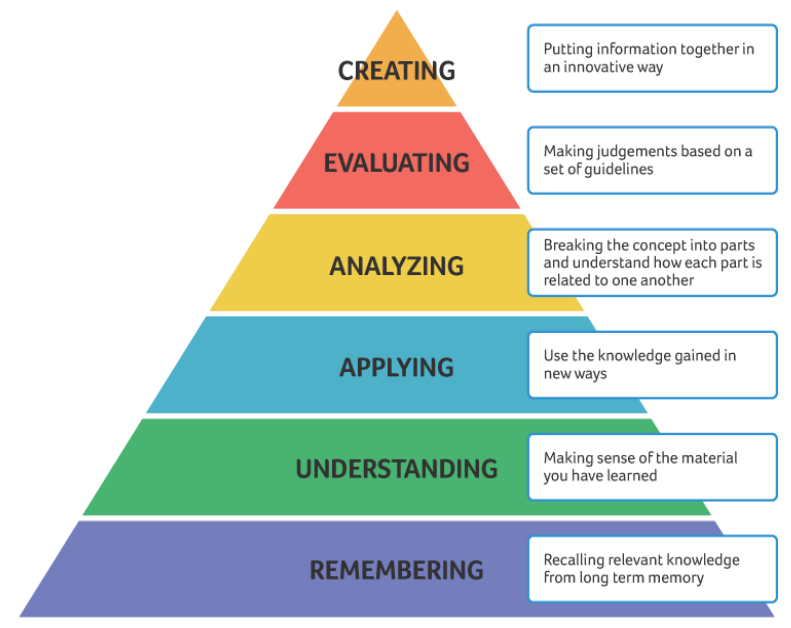

Figure 1: Bloom's taxonomy of learning objectives

Remembering means retrieving and recalling relevant knowledge or facts from long-term memory. An example of remembering activities could be a listening comprehension exercise. At the Understanding level, students should be able to summarize a news report or translate a sentence or text. Students can apply what they learn if they use the grammatical rules or vocabulary they cover in a lesson in their digital stories, conversations, or debates. Analyzing activities can be more challenging to the learners. They might categorize the argument of a debate into constituent parts, key ideas, or hyper-themes. At the Evaluating level, students should be able to evaluate a recording or oral presentation based on checklists and rubrics. Finally, Creating requires more evidence of active learning on the part of the learners. Digital storytelling is an example of a Creating activity.

The Technology Integration Matrix (TIM), which constitutes the second component of our theoretical framework, is based on the concept of meaningful learning. Meaningful learning environments have five characteristics, namely, Active, Collaborative, Constructive, Authentic, and Goal-Directed. TIM associates these five characteristics with five levels of technology integration: Entry, Adoption, Adaptation, Infusion, and Transformation. In other words, active learning increases on a continuum from entry to transformation. One of the underlying principles of TIM is associated with the ownership of learning. There is a gradual shift from a teacher-centered approach to learning, to student-centered learning at higher levels. That is, at an initial stage, technology is mostly used by the teachers, who are required to train the students in how to use it. When students become more advanced, they are empowered enough to select a technology and to use it to achieve certain learning outcomes, as shown in Figure 2.

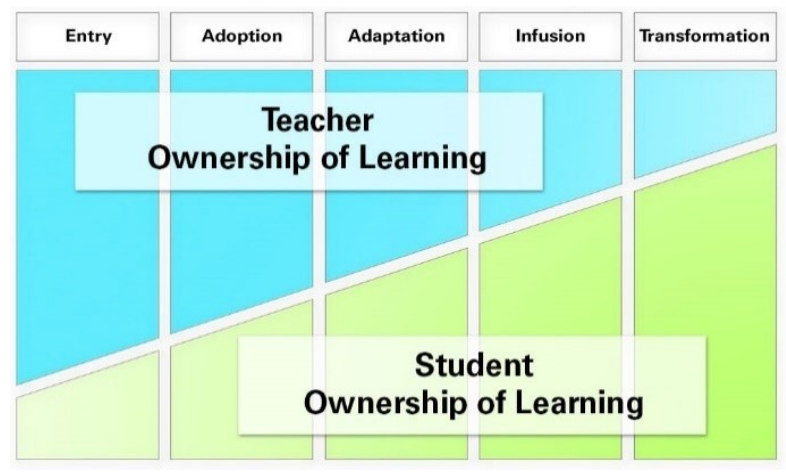

Figure 2: Ownership of learning in TIM (Winkelman, 2019) 
Another significant underlying principle behind the TIM method is that higher levels of technology integration require higher-order thinking on the part of the students, as Figure 3 shows.

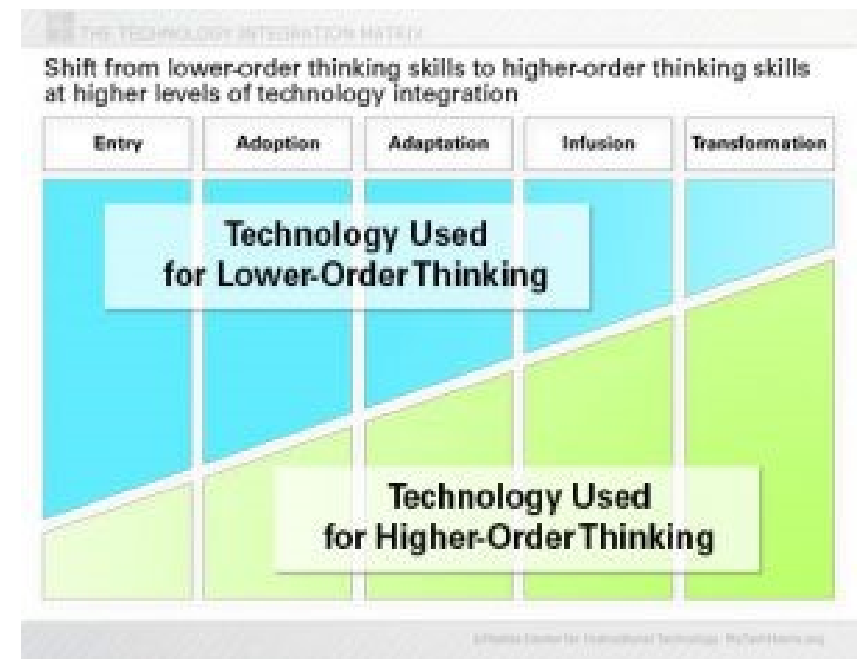

Figure 3: Bloom's lower-order and higher-order thinking and TIM (Winkelman, 2020)

Hence, Bloom's taxonomy and TIM should not be used independently. Technology can be integrated across all levels of Bloom's taxonomy. The Entry and Adoption levels provide the technological foundations for learners. To effectively build upon these levels, students must acquire knowledge and skills that enable them to use various technological tools in conventional ways. Students can use technology to perform lower-order thinking activities. On the other hand, activities in which students use technology to evaluate content, assess their peers, or perform analysis show that learners are capable of Adapting and Infusing technology. The use of technology to create activities and language resources is part of the transformational potential of TIM. At the Transformation stage, optimal use of technology is reached. Students may start to use technological tools innovatively. Hence, the integration of Bloom's taxonomy and TIM enables language teachers to design tasks with clearly defined learning outcomes. An array of interesting and motivating learning activities that were previously inconceivable, can be designed. The following section demonstrates how the two models are integrated in a fully online listening and speaking course.

\section{The Designed Syllabus}

The designed syllabus aims to develop the listening and speaking skills of Arabic learners through several interactive activities and resources. It consists of five chronological learning units that were taught in the first semester of the 2020 South African academic year (March 2020 - July 2020). Each chronological unit is composed of various theme-specific lessons with clear learning outcomes. It consists of three components: listening, speaking and conversational Arabic. The content can be updated, and topics be changed if necessary. Table 1 provides a list of the course modules and contents in its present/initial form.

Table 1: Modules and contents of the designed course

\begin{tabular}{|c|l|l|l|}
\hline $\begin{array}{c}\text { Unit } \\
\begin{array}{c}\text { Unit } \\
1\end{array}\end{array}$ & \multicolumn{1}{|c|}{ Listening Modules } & \multicolumn{1}{|c|}{ Speaking Modules } & \multicolumn{1}{|c|}{ Conversational Arabic } \\
\hline $\begin{array}{c}\text { Unit } \\
2\end{array}$ & Children and violence & $\begin{array}{l}\text { Sectarianism in Middle East } \\
\text { countries }\end{array}$ & $\begin{array}{l}\text { Fashion (YouTube-based lesson) } \\
\text { Hajj and Umrah occasions }\end{array}$ \\
\hline $\begin{array}{c}\text { Unit } \\
3\end{array}$ & $\begin{array}{l}\text { Mawlid (celebration of the birthday of } \\
\text { the Prophet Muhammad) and Christmas } \\
\text { in Cape Town }\end{array}$ & $\begin{array}{l}\text { Social justice \& minority } \\
\text { rights }\end{array}$ & $\begin{array}{l}\text { Joha and the tent (YouTube- } \\
\text { based lesson) } \\
\text { Social occasions (Marriage) }\end{array}$ \\
\hline $\begin{array}{c}\text { Unit } \\
4\end{array}$ & $\begin{array}{l}\text { Halal industry } \\
\text { lesson) in the Zoo (YouTube-based } \\
\text { Visiting the sick }\end{array}$ \\
\hline $\begin{array}{c}\text { Unit } \\
5\end{array}$ & $\begin{array}{l}\text { Wasatiyyah (Moderation; literally the } \\
\text { "middle way" in Islam) }\end{array}$ & $\begin{array}{l}\text { Redistribution of land in } \\
\text { South Africa }\end{array}$ & $\begin{array}{l}\text { Joha and Water (YouTube-based } \\
\text { lesson) } \\
\text { Celebrating a newborn }\end{array}$ \\
\hline
\end{tabular}


The entire course was presented in NEO LMS as the snapshot in Figure 4 shows.

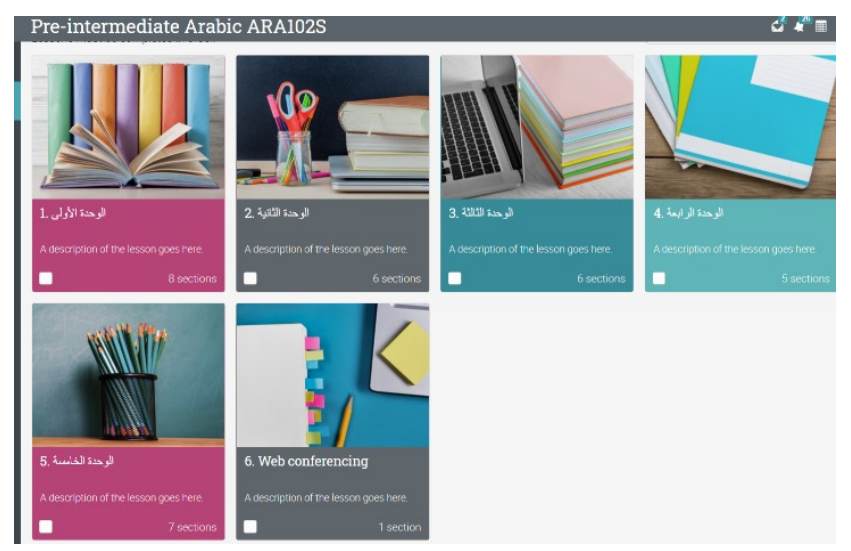

Figure 4: Course interface in NEO

The resources for the course included YouTube videos, socio-economic issues, religious texts, and dialogue simulations, among others. The activities in each unit were based on the learning outcomes for each lesson. They were aligned with Bloom's taxonomy and the TIM's five levels of technology integration. Table 2 gives an overview of the activities in one of the units

Table 2: Integration of TIM and Bloom's taxonomy in the syllabus

\begin{tabular}{|l|l|l|}
\hline TIM & Bloom & Activity \\
\hline Transformation & Creating & Debate, simulation, discussion, wikis, digital storytelling \\
\hline Infusion & Evaluating & Evaluate a peer-spoken activity \\
Adaptation & Analyzing & Oral presentation, short dialogue \\
\hline Adoption & Applying & Subtitling \\
\hline Entry & Understanding & Summary of a video/ vocabulary work \\
\hline Entry & Remembering & Listening comprehension \\
\hline
\end{tabular}

Navigating back and forth between the various units with their different components can be potentially cumbersome. Thus, a user-friendly course layout optimizes effective language teaching and learning on a digital platform. The landing page of the course includes all the units and lessons of the course and learners can move freely between units and lessons, as shown in Figure 5.

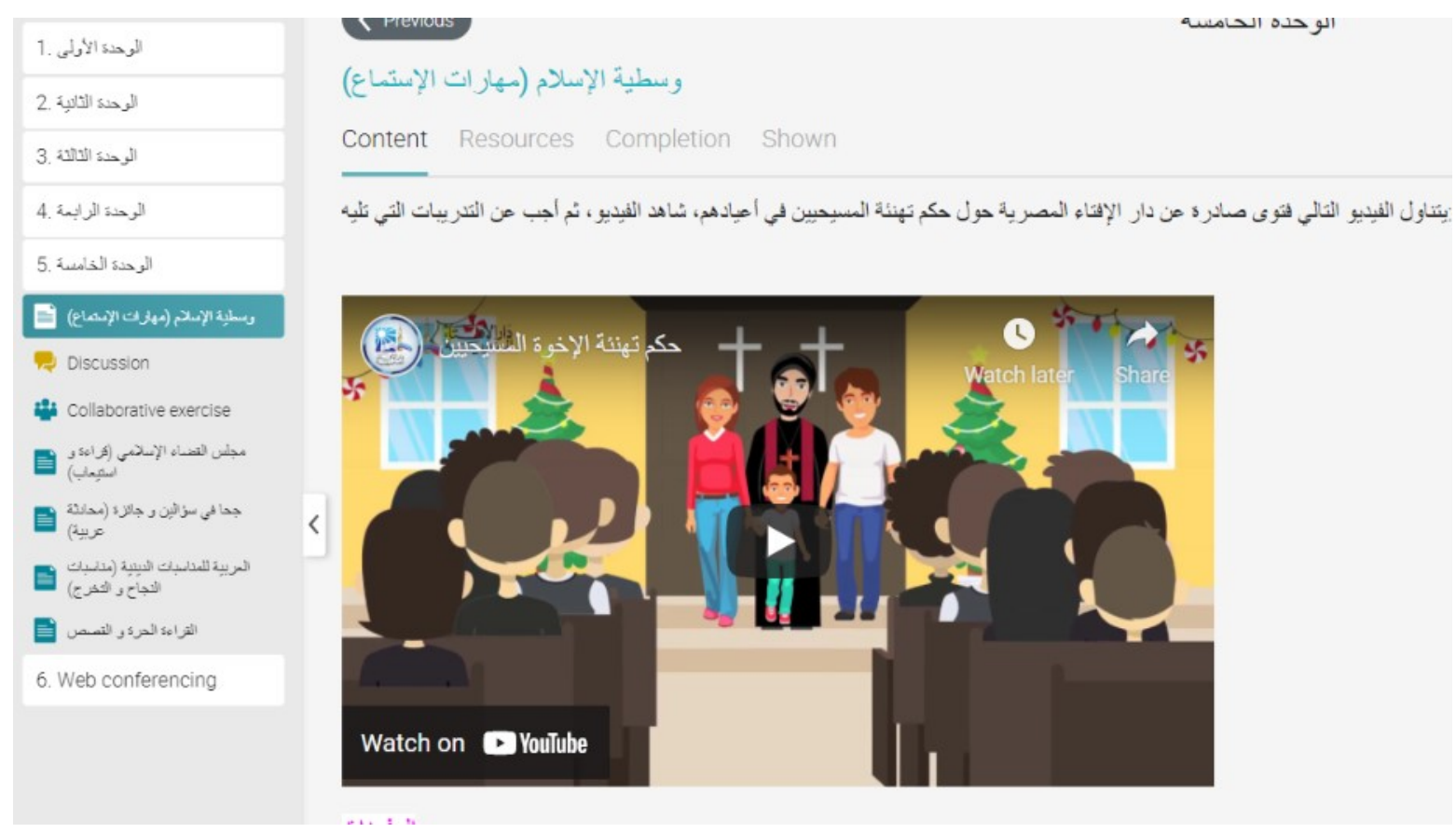

Figure 5: The landing page of the course 
While the LMS can be highly beneficial in teaching some language skills, it may not be so for teaching speaking and listening. Thus, the use of education technology specifications such as LTI can be especially useful for the latter skills. LTI integration allows for the use of learning tools from different vendors to be used within a LMS. However, not all learning management systems are LTI-compliant, and the use of this feature is not always straightforward. In addition, free versions of LMSs may not provide LTI integration at all. Moreover, some tools are not compatible with Learning Tools Interoperability (LTI) specifications. Nevertheless, third party Web 2.0 tools can also be integrated into the LMS without the use of LTI education technology specifications either through direct links, embedded source code, SCORM, or HTML5 Package (H5P) format activities. The course in this study has utilized several of these tools to create effective integrated activities and to make them available to students in a single software. The use of these tools, with their robust features can guarantee a fully online course that permits high levels of interactivity and timely feedback. It is worth mentioning that the learning activities vary from one lesson to another. There is no single model, or a one-size-fits-all policy that can be used in every lesson. Although the syllabus is designed for AFL learners at a South African tertiary institution, the model can be applied in its entirety, or with idiosyncratic adjustments, to design fully online or blended courses at other institutions. In what follows, some of the activities and resources used in the three components of the syllabus are discussed.

\subsection{Listening}

Listening lessons start with a pre-listening activity which students typically complete during the first five minutes of a synchronous web-conferencing session, by posting their answers via the LMS discussion forum, or by giving an oral presentation through a Sanako Connect Lab. The listening lesson is then presented to the students. Students are required to listen to or watch a two-minute report or YouTube video and are encouraged to take notes. Figure 6 below gives a screenshot of a listening multimedia resource.

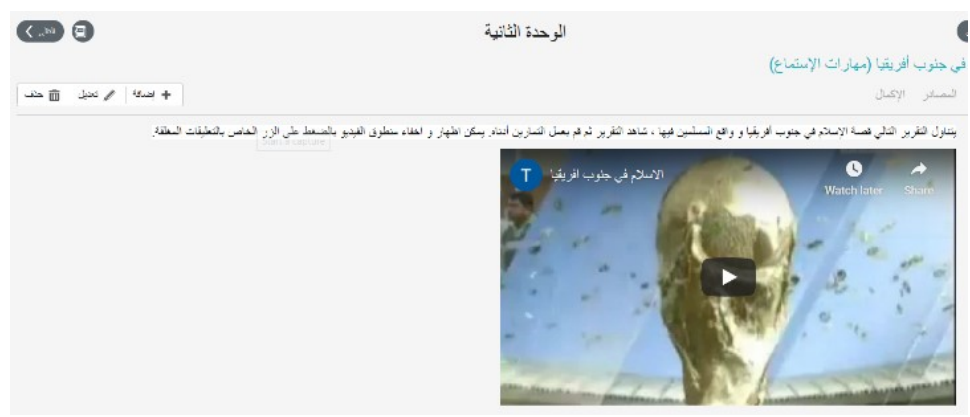

Figure 6: Listening multimedia resource in NEO

After watching or listening to the video, students are requested to perform various types of interactive or gamified exercises such as vocabulary quizzes, listening comprehension questions, multiple-choices and/or matching exercises, as shown in Figure 7 below.

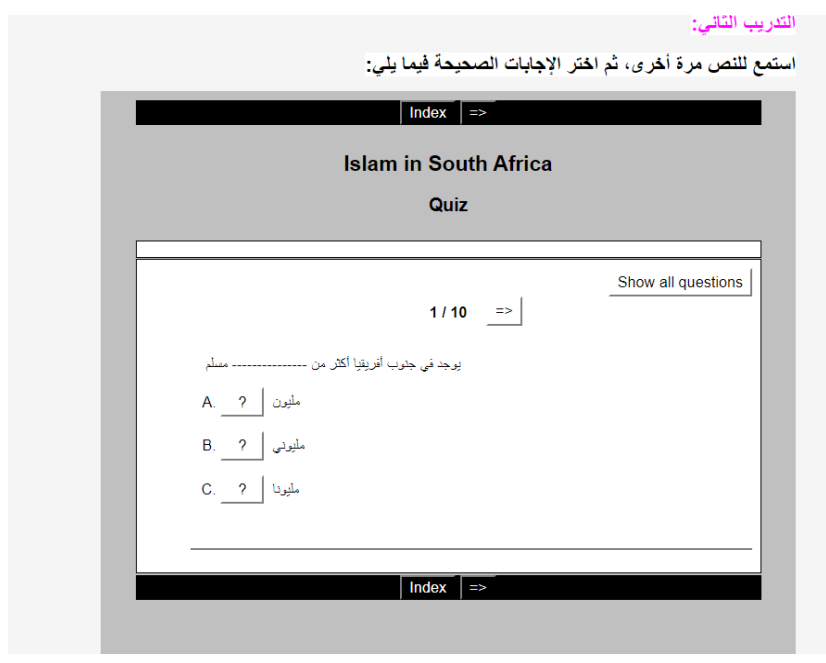

Figure 7: Listening comprehension activity embedded in NEO 
Students are also required to compose sentences in which they use words or expressions they have learned in the lesson. They might also be assigned to listen to the report and provide a transcript and English subtitles for it. They may also be asked to record their own one-minute discussion about a lesson-related topic, as shown in Figure 8.

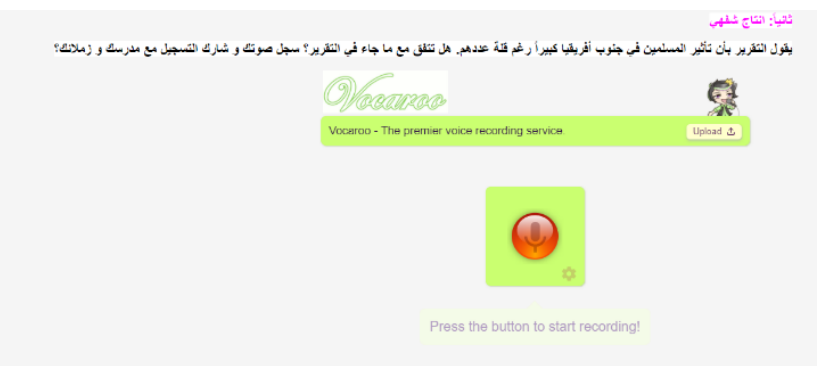

Figure 8: A Vocaroo recording activity embedded in NEO

\subsection{Conversational Arabic}

The Conversational Arabic component utilizes authentic conversational texts that deal with various topics such as water crises, fashion, technology, internet, examinations, and etcetera. Lessons typically start with a short conversational video. Then, students are required to summarize the video orally. Later, a full transcript of the video is made available. The students are then encouraged to watch the video again. They then role play the conversation. Finally, an H5P activity was created for each lesson. H5P activities usually include several in-video comprehension questions to test students' understanding, as shown in Figure 9.

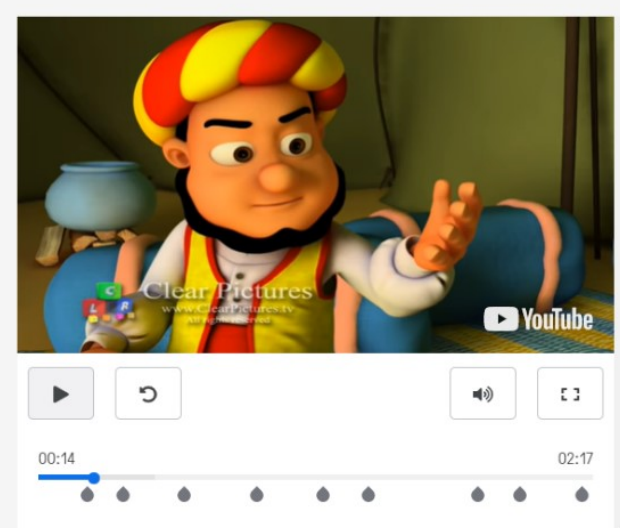

Figure 9: H5P interactive video quiz embedded in NEO

Each conversational Arabic lesson includes a dialogue simulation, which consists of various branching scenarios, as is clear in Figure 10.

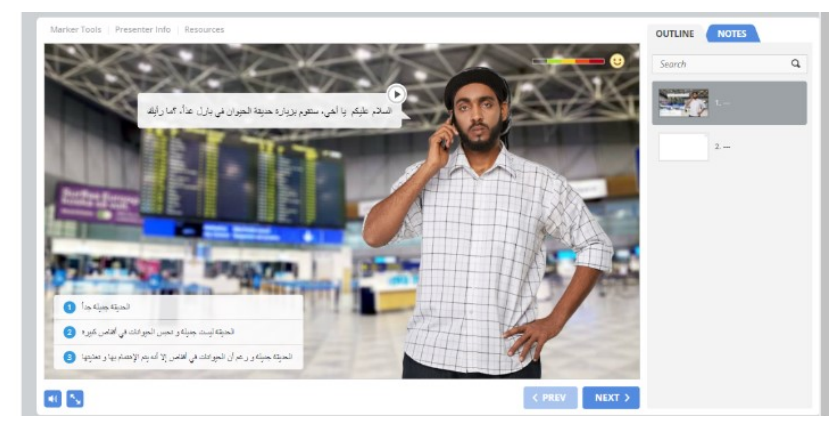

Figure 10: Dialogue simulation activity

A branching scenario is an interactive activity that enables learners to practice communication skills using multichoice narratives. Simulation activities are ideal for the practice and enhancement of communication skills. The time limitations of teacher-led instruction can make it difficult to cover certain types of conversations, for 
instance, a conversation at an airport. A dialogue simulation, on the other hand, can consist of several topicrelated scenarios or dialogues, where learners can practice each one individually. Simulation can be created using authoring tools such as ActivePresenter, Ispring or branchtrack.

\subsection{Speaking}

The speaking component consists of many discussion topics, debates, and Wikis. Students are encouraged to talk about topics such as land distribution in South Africa, COVID-19, crime, polygamy, social services, and domestic violence, among others. For synchronous discussions, debates, role-plays and real-life dialogues, the course uses Sanako Connect. Students are divided into pairs or groups and are asked to engage in discussion as if they are in a physical class. Sanako Connect recreates the same experience of a physical language lab and is often referred to as a language lab in a browser. Teachers can share their screen, speak, or listen to one student or the entire class.

The syllabus also includes more advanced skills and activities such as consecutive and simultaneous interpreting. For this purpose, the course also uses Sanako Connect. Students can listen to a master track and insert their interpretation or voice into the video, as shown in Figure 11. This feature is particularly ideal for consecutive interpreting activities, a feature that video editing software often lack.

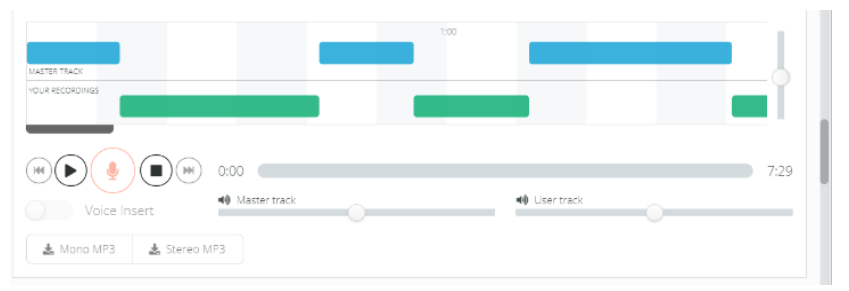

Figure 11: Consecutive interpreting in Sanako Connect

Sanako Connect facilitates all speaking, listening, and interpreting tasks that typically take place in a physical language lab. Speaking assignments such as debates, discussions, and Wikis were also created straight in NEO LMS, as is obvious in Figure 12.

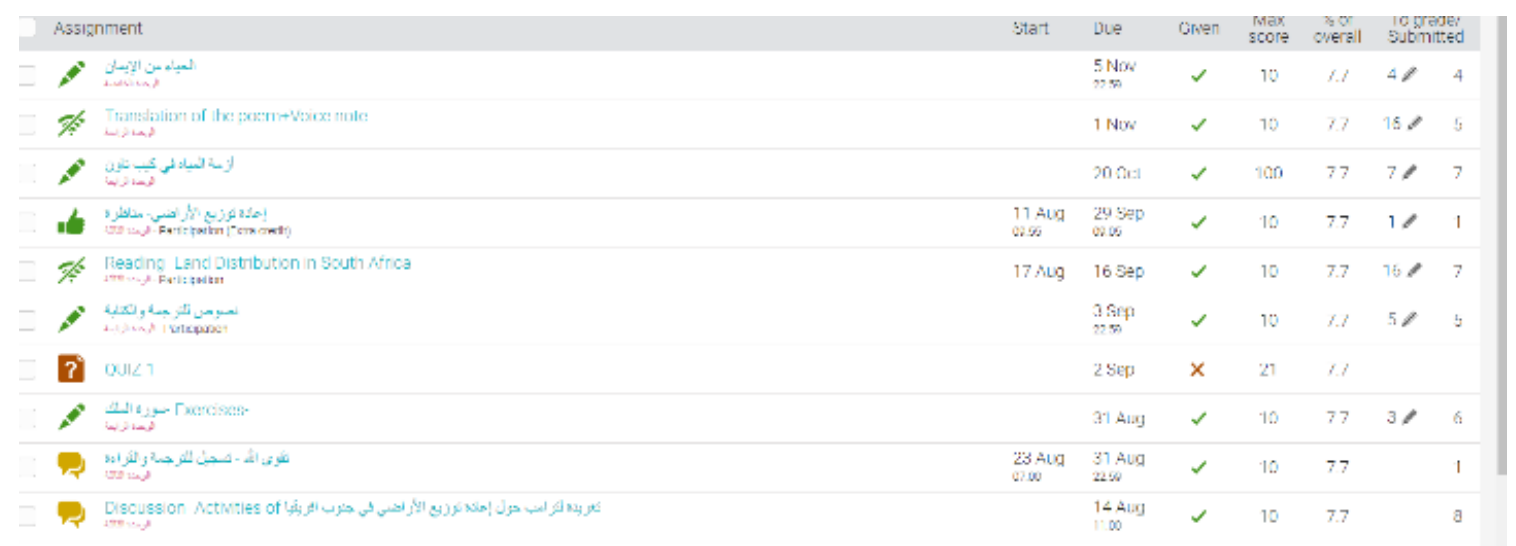

Figure 12: Assignments in NEO LMS

The system ensures the optimal use of these activities. Students can write, chat, and speak to each other. They can also submit written or recorded comments on their classmates' responses. Instructors facilitate and monitor the discussion or debate, and provide feedback on the students' participation.

Using features such as SCORM allows for the integration of PowerPoint presentations for each lesson along with recorded narratives and graded interactive quizzes. These quizzes can incorporate constructive feedback to enrich the effectiveness of instruction. In addition, a SCORM package can be compressed into a ZIP file, and thus can be downloaded for offline use. 


\section{Materials and Methods}

This study is descriptive-analytical in its structure. It describes a listening and speaking syllabus that was presented remotely via a LMS system during the first COVID-19 lockdown in South Africa. It also employs a quantitative approach through a questionnaire composed of 30 five-point Likert items, to investigate the attitudes of AFL students at IPSA towards the syllabus.

\subsection{Participants}

The respondents of the present study were thirty-one AFL students at IPSA. The participants constitute all registered students in the Bachelor of Arts program in their second or third years of study.

\subsection{Instrument and Procedures}

To investigate the perceptions of the students towards the online Arabic speaking and listening course, a questionnaire was developed for this study. The following steps were considered in the development of the questionnaire:

1. Conduction of semi-structured interviews with fifteen AFL students from the IPSA student population. The students were asked some questions and were also given the opportunity to raise their own questions. The questions were then reviewed by two specialists in the field. Such interviews enabled us to "draw up an item pool" (Dörnyei, 2007, p17). A forty-four-item questionnaire was prepared in the beginning.

2. The questionnaire was reviewed by two professors of Applied Linguistics who suggested the deletion of eight items. An initial pilot study was then conducted with ten AFL students from the IPSA population. The rationale behind the pilot study was to ensure the comprehensibility and clarity of the questionnaire's items. A Principal Component Analysis (PCA) was also conducted before analyzing the questionnaire's reliability. Based on the experts' recommendations, the outcome of the pilot study, and the PCA, six items which were reported as poorly understood were omitted, along with eight other irrelevant items. The questionnaire in its final form was reduced to thirty items.

3. The thirty-item questionnaire was then administered to thirty-one AFL students, none of whom had participated in the pilot study. The reliability of the questionnaire was calculated using Cronbach's alpha consistency, which reveals the questionnaire demonstrated an acceptable internal consistency $(r=0.87)$.

For statistical analysis, the participants' attitudes towards the designed course were categorized into three levels: high, medium, and low, as follows:

- From 1.00 to 2.60 indicates a mean of low value.

- From 2.61 to 3.40 indicates a mean of medium value.

- From 3.41 to 5.00 indicates a high value mean.

The statistical significance was analyzed using various statistical models, including descriptive statistics and ttests, as appropriate.

\section{Results}

To investigate the attitudes of the AFL students at IPSA towards the speaking and listening online course, the means, standard deviations, and percentages of each item across all the participants were calculated. For this purpose, GNU PSPP, a program for statistical analysis of sampled data, was used. Table 3 shows the students' responses to the resources in the syllabus.

Table 3: Students' perceptions of the resources in the course

\begin{tabular}{|c|c|c|c|c|c|c|c|c|}
\hline \multirow[b]{2}{*}{ No } & \multirow[b]{2}{*}{ Items } & \multicolumn{5}{|c|}{ Percentages (\%) } & \multirow[b]{2}{*}{ Mean } & \multirow[b]{2}{*}{ SD } \\
\hline & & 1 & 2 & 3 & 4 & 5 & & \\
\hline 1 & $\begin{array}{l}\text { The course introduced authentic texts } \\
\text { produced by native speakers. }\end{array}$ & & & 3.23 & 12.90 & 83.87 & 4.81 & .48 \\
\hline 2 & $\begin{array}{l}\text { The materials represent various text- } \\
\text { types. }\end{array}$ & 6.45 & 16.13 & 48.39 & 16.13 & 12.90 & 3.13 & 1.06 \\
\hline 3 & $\begin{array}{l}\text { The course is student-focused to a great } \\
\text { extent. }\end{array}$ & 6.45 & 6.45 & 6.45 & 16.13 & 64.52 & 4.26 & 1.24 \\
\hline 4 & $\begin{array}{l}\text { The course provides self-paced and } \\
\text { personalized materials. }\end{array}$ & 6.45 & 6.45 & 3.23 & 16.13 & 67.74 & 4.32 & 1.22 \\
\hline
\end{tabular}




\begin{tabular}{|c|c|c|c|c|c|c|c|c|}
\hline \multirow[b]{2}{*}{ No } & \multirow[b]{2}{*}{ Items } & \multicolumn{5}{|c|}{ Percentages (\%) } & \multirow[b]{2}{*}{ Mean } & \multirow[b]{2}{*}{ SD } \\
\hline & & 1 & 2 & 3 & 4 & 5 & & \\
\hline 5 & $\begin{array}{l}\text { The topics selected in the course are } \\
\text { graded in terms of content and } \\
\text { difficulty. }\end{array}$ & 9.68 & & 9.68 & 16.13 & 64.52 & 4.26 & 1.26 \\
\hline 6 & $\begin{array}{l}\text { Resources cater for various learning } \\
\text { styles. }\end{array}$ & 6.45 & & 6.45 & 19.35 & 67.74 & 4.42 & 1.09 \\
\hline 7 & The teaching methodology is effective. & 3.23 & 3.23 & 9.68 & 35.48 & 48.39 & 4.23 & .99 \\
\hline 8 & $\begin{array}{l}\text { I have learned new vocabulary in my } \\
\text { speaking classes. }\end{array}$ & 6.45 & & 3.23 & 16.13 & 74.19 & 4.52 & 1.06 \\
\hline 9 & My pronunciation improved. & 6.45 & & 9.68 & 16.13 & 76.74 & 4.39 & 1.12 \\
\hline 10 & $\begin{array}{l}\text { The speaking class has a positive effect } \\
\text { on my accuracy while speaking. }\end{array}$ & 3.23 & 3.23 & 9.68 & 12.90 & 70.97 & 4.45 & 1.03 \\
\hline 11 & $\begin{array}{l}\text { The speaking class helps improve my } \\
\text { fluency in speaking. }\end{array}$ & 3.23 & & 9.68 & 19.35 & 67.74 & 4.48 & .93 \\
\hline 12 & $\begin{array}{l}\text { The course enriched my knowledge of } \\
\text { idiomatic expressions, collocations, and } \\
\text { proverbs. }\end{array}$ & 6.45 & 3.23 & 6.45 & 9.68 & 74.19 & 4.42 & 1.18 \\
\hline 13 & $\begin{array}{l}\text { The course enhanced my Arabic } \\
\text { grammar usage. }\end{array}$ & 6.45 & 6.45 & 3.23 & 19.35 & 64.52 & 4.29 & 1.22 \\
\hline 14 & $\begin{array}{l}\text { The course enhanced my acquisition of } \\
\text { various speech acts in Arabic }\end{array}$ & 6.45 & 3.23 & 3.23 & 12.90 & 74.19 & 4.45 & 1.15 \\
\hline \multirow[t]{2}{*}{15} & $\begin{array}{l}\text { The course enhanced my proficiency } \\
\text { and communicative competence. }\end{array}$ & 6.45 & 9.68 & 12.90 & 6.45 & 64.52 & 4.13 & 1.34 \\
\hline & & \multicolumn{2}{|l|}{9.46} & 9.67 & \multicolumn{2}{|l|}{81.45} & 4.30 & 1.09 \\
\hline
\end{tabular}

As the data in Table 3 shows, the average for items in the relevant section of the questionnaire ranged from (3.13) to (4.81) with corresponding percentages from (76.65\%) to (96.77\%). This indicates a medium to high level of agreement on all items. The emerging statistics reveal that the participants of this study identified that the resources of the course are satisfactory.

As for the learning activities of the course, respondents were asked to rate their effectiveness on a five-point scale: 'not at all effective', 'somehow ineffective', 'neutral', 'quite effective', and 'extremely effective'. Table 4 shows the responses of the students to the activities of the online course.

Table 4: Students' perceptions towards the activities of the course

\begin{tabular}{|c|c|c|c|c|c|c|c|c|}
\hline \multirow[b]{2}{*}{ No. } & \multirow[b]{2}{*}{ Activities } & \multicolumn{5}{|c|}{ Percentages (\%) } & \multirow[b]{2}{*}{ Mean } & \multirow[b]{2}{*}{ SD } \\
\hline & & 1 & 2 & 3 & 4 & 5 & & \\
\hline 16 & Zoom sessions and Zoom breakout rooms & 6.45 & 9.68 & 9.68 & 9.68 & 64.52 & 4.16 & 1.32 \\
\hline 17 & Interactive videos & & & 12.90 & 9.68 & 77.42 & 4.65 & .71 \\
\hline 18 & Listening activities & 6.45 & 9.68 & & 9.68 & 74.19 & 4.35 & 1.28 \\
\hline 19 & Vocabulary quizzes & 6.45 & 9.68 & 6.45 & 9.68 & 67.74 & 4.23 & 1.31 \\
\hline 20 & Discussion forums & 6.45 & 12.90 & 45.16 & 16.13 & 19.35 & 3.29 & 1.13 \\
\hline 21 & Debating & & 3.23 & 9.68 & 12.90 & 74.19 & 4.58 & .81 \\
\hline 22 & Wikis and chats & 6.45 & 6.45 & 6.45 & 12.90 & 67.74 & 4.29 & 1.24 \\
\hline 23 & Game-based activities & 6.45 & 6.45 & 6.45 & 6.45 & 74.19 & 4.35 & 1.25 \\
\hline 24 & Role-playing & 3.23 & 6.45 & 12.90 & 6.45 & 70.97 & 4.35 & 1.14 \\
\hline 25 & Digital storytelling & & & 9.68 & 9.68 & 80.65 & 4.71 & .64 \\
\hline 26 & Oral recording & 3.23 & 6.45 & 9.68 & 6.45 & 74.19 & 4.42 & 1.12 \\
\hline 27 & Peer assessment tasks & 6.45 & 6.45 & 6.45 & 6.45 & 74.19 & 4.35 & 1.25 \\
\hline 28 & Sanako Connect speaking activities & 6.45 & & 6.45 & 19.35 & 67.74 & 4.42 & 1.09 \\
\hline 29 & Interpreting activities & 3.23 & 3.23 & 6.45 & 19.35 & 67.74 & 4.45 & .99 \\
\hline 30 & Simulation activities & 6.45 & & 9.68 & 9.68 & 74.19 & 4.45 & 1.12 \\
\hline \multicolumn{2}{|c|}{ Average of Each Point } & \multicolumn{2}{|c|}{$9.89 \%$} & 10.57 & \multicolumn{2}{|c|}{$79.56 \%$} & 4.33 & 1.09 \\
\hline
\end{tabular}

As the data in Table 4 shows, the average for items in the relevant section of the questionnaire ranged from (4.16) to (4.71) with corresponding percentages from (74.2\%) to (93.398\%). This indicates a high level of agreement on all items. The emerging statistics reveal that the participants in this study identified that the activities of the course were highly effective. In addition to the analysis of the attitudes of the respondents 
towards various aspects of the syllabus, this study also analyzed their overall attitude towards the syllabus. For this purpose, a t-test for one sample was used. The results of the t-test are given in tables 5 and 6 , respectively.

Table 5: One-sample statistics

\begin{tabular}{|l|l|l|l|l|}
\hline \multicolumn{5}{|c|}{ One-Sample Statistics } \\
\hline & $N$ & Mean & Std. Deviation & S.E. Mean \\
\hline Sum & 31 & 129,61 & 15,24 & 2,74 \\
\hline
\end{tabular}

Table 6: One-sample test

\begin{tabular}{|c|c|c|c|c|c|c|}
\hline \multicolumn{7}{|c|}{ One-Sample Test } \\
\hline & \multicolumn{6}{|c|}{ Test Value $=120,000000$} \\
\hline & & & & & $95 \% \mathrm{Cc}$ & ral of the Difference \\
\hline & $\mathrm{t}$ & $\mathrm{df}$ & Sig. (2-tailed) & Mean Difference & Lower & Upper \\
\hline Sum & 3,51 & 30 & ,001 & 9,61 & 4,02 & 15,20 \\
\hline
\end{tabular}

It is clear from the above tables that the t-test value is 3.51 with a significance level of 0.001 . That is, the respondents' overall attitude towards the online course was positive and is statistically significant at $p<.05$.

\section{Discussion}

This section discusses the attitudes of the AFL students who completed the course towards the course's resources and activities, as understood from the findings of the questionnaire. The findings showed a high degree of satisfaction concerning the resources of the course. In the view of the respondents, the course introduced authentic TV broadcasts, conversations, and discussions produced by native speakers which are mostly related to a South African context. Some of the texts are presented by Arab native speakers and represent various genres or text-types. The course includes news reports, narratives, stories, dialogues about health as well as religious, economic, and social problems. The finding of this study is in line with others that show the significance of using authentic materials in teaching a foreign language (Oğuz and Bahar, 2008; Johnson, 2016; Rao, 2019).

The respondents also generally agreed that the resources of the course are student focused. The course puts the student at the center of the learning process. Students were given clear instructions on how to navigate the materials and what they were supposed to do before-, during, and after each lesson. The progress of the students was also tracked via the LMS. The role of the instructor was to facilitate, monitor, and assist the students during different stages of the course. The positive impact of learner-centered education on the achievement of the learners was also confirmed in several previous studies (Tullis and Benjamin, 2011; Wang, 2017; Arvanitis, 2019).

The syllabus also acknowledges individual differences among students, and the need to personalize learning (Dolog et al., 2004; Kukulska-Hulme, 2016) by allowing students to navigate the materials at their own pace. The topics were selected and presented very carefully in terms of information load and difficulty, with easier topics first and more challenging ones later. The findings from the questionnaire also showed that the course caters to various learning styles. The course strikes a balance among various modalities (Guichon and Cohen, 2016; Lebedeva, 2018). Texts, images, interactive videos, recordings, digital stories, and the like were presented in the course. Respondents also agreed that the teaching methodology was effective. The student-teacher interaction took place synchronously through web conferencing tools such as Zoom, Google Meet, and Microsoft Teams, and asynchronously through LMS. The alignment of materials and activities with clear learning outcomes (Amin and Mirza, 2020) made it easier for the students to cope with the requirements of the course. Interactive activities were carefully designed and included constructive feedback. The videos were subtitled, and recordings of lectures were made available to the students via LMS. All of these could have positively influenced the students towards a favorable view of the teaching methodology.

Moreover, the findings of the study showed that the syllabus generally enhanced the learners' skills and their communicative competence. Their usage of lexical items, idioms, and collocations in discussion forums and debates conducted online showed noticeable improvement in their lexico-grammatical competence. The respondents also agreed that their pronunciation, self-efficacy, and confidence improved. This was also clear in their participation in oral presentations and recordings. Although the recordings abound with pronunciation errors, this is typically understood as natural and a part of learning (Touchie, 1986). In the beginning, students 
were reluctant to produce a one-minute recording, but weeks after the initiation of the course, their participation and confidence improved dramatically. The increased fluency and accuracy of students were both noticeable. This was also articulated by respondents who agreed that their speaking, listening, and communicative competence in general showed improvement.

When respondents were asked to rate the speaking and listening activities presented in their online course, they reported positive attitudes towards the activities. Respondents liked the Zoom sessions and especially the breakout room activities. Zoom sessions can be very boring (Toney, Light and Urbaczewski, 2021) if not supplemented by breakout room activities such as role-playing or discussion, or comprehension exercises.

Students also agreed that interactive videos were very effective. In these mostly interactive H5P activities, students were asked to watch a video and answer questions that were inserted into the video to assess their comprehension. Respondents also found the listening activities effective. Most of these activities were prepared as SCORM packages and included answers and constructive feedback. Vocabulary quizzes were prepared for each lesson and were gamified using a Web 2.0 tool called Quizlet before they were embedded in the LMS system. Students rated them as extremely effective. Discussion forums, debates, wikis, and role-play were also integrated into different lessons throughout the course using the functionalities of the LMS and Sanako Connect. Students also rated these as highly effective. The gamification of the content was developed using several gamebased activities that were created using Smart Notebook, Wordwall, and Kahoot and were also rated by the students as effective. These findings have been corroborated by previous studies which acknowledge the role of gamification in achievement and motivation of students (Flores, 2015; Udjaja, 2018; Dehghanzadeh et al., 2019).

The findings also emphasized the benefits of project-based learning, such as digital storytelling in which students practice their language skills using images, videos, texts, scripts, and recordings (Robin, 2008; Liu, Tai and Liu, 2018). The findings also revealed that there were commonalities among the students' responses concerning the effectiveness of peer assessment tasks (Spiller, 2012; Fathi, Mohammad Yousefi and Sedighravesh, 2017).

Furthermore, students reported positive attitudes towards speaking activities, which were conducted via Sanako Connect. This digital web-based lab enabled them to be involved in real-time discussions and conversations that at the time this study was conducted were not possible without this technology. Interpreting activities, both simultaneous and consecutive, were also integrated into the course and the respondents found them extremely effective. Of special interest are the consecutive interpreting activities, during which students listen to a portion of a recording and insert their translation/interpretation, and then they continue to translate the entire video.

Simulation was also utilized in the course to teach dialogues and conversations. Students were introduced to conversations that are generally not implemented in a physical class setting due to time limitations (Coleman and Yamazaki, 2018).

\section{Conclusion}

Speaking and listening are highly demanding and multi-faceted language skills, especially for non-native learners. The transition to remote learning due to COVID-19 created added burdens on both teachers and learners. However, while the pedagogical literature abounds in explanations for designing materials for building reading skills, grammar, and vocabulary, it largely lacks the same depth for designing learning prototypes that can enhance listening and speaking skills. There is an obvious need for the use of well-established e-learning ecologies such as LTI and SCORM-compliant learning management systems, which can enable syllabus designers and teachers to provide more effective materials for the language classroom. Special attention needs to be given to skills that require more intensive effort and advanced skills on the part of the learners, including speaking and listening.

This study explored the design of a fully online course for teaching Arabic speaking and listening skills in a South African context during the COVID-19 pandemic, as well as the effectiveness of the course for improving students' language skills and linguistic competence. The study provided a detailed description of the resources and activities of the course and its delivery. It revealed that the students were satisfied with the content of the course, including its authentic topics, resources, and activities. This study also demonstrated that the course caters for a variety of student linguistic and psychological needs and considers individual differences and 
learning styles. The students reported that they were impressed with the multimodality of the course. In addition to the textbook, the course employed the use of supplemental texts, and audio and video materials. It also introduced a considerable number of dialogue simulations, debates, and discussions. The study findings identified that the course syllabus enhanced learners' linguistic competence, accuracy, and fluency. The course content also enhanced their motivation, self-efficacy and self-regulated learning. For ease of accessibility, the course was entirely delivered on NEO LMS. The technology-enhanced activities and resources were not only based on the features of the LMS, but also utilized various tools and standards such as Web 2.0 tools, SCORM packages and LTI features. Although the study used NEO LMS as a platform for the delivery of the course, the technology-enhanced approach adopted in this study can be applied in other LMS platforms or sites such as Google or WordPress. Language teachers can use the model presented in this study in its entirety or with modifications to revamp their language courses, while taking into consideration students' satisfaction levels and needs. This course format has the potential to serve as a basis for teachers to design online, blended, and faceto-face courses that are likely to suit in the "new normal" in a post-COVID-19 environment.

This study focused on the design of a remote speaking and listening syllabus for teaching Arabic as a foreign language. Future research may expand these results by designing syllabi for the same skills in other languages, or by designing learning prototypes for other language skills. Moreover, this research study investigated a syllabus, which was designed and taught by the researcher. It also investigated the perceptions of the learners towards the designed syllabus based on a small size sample, although the sample included the entire population of AFL learners at the site of research. Therefore, the findings of the study cannot be generalized for a larger population. The syllabus presented in this study needs to be implemented with other groups of students and taught by more instructors. The attitudes of both students and teachers need to be investigated both qualitatively and quantitatively. In addition, the impact of the syllabus may be investigated in other language contexts and institutions. Finally, future research work could analyze the possible differences in impact among students according to many variables such as gender, language level, computer literacy, e-learning ecologies, and e-learning specifications.

\section{References}

Abdullah, A., 2015. Itijahāt al-mudarisīn wa al-Ṭalabah fỉ Burnaay Dār al-Salām naḥwa istikhdām shabakāt al-tawașul aligtimāī fĩ ta'līm al-lughah al-'arabiyah. Majalat Al-Dirāsāt Al-Lughawiyah Wa Al-Adabiyah, (5), pp. 117-44.

Al Rawashdeh, A. Z., Mohammed, E., Al Arab, A., Alara, M. and Al-Rawashdeh, B., 2021. Advantages and disadvantages of using e-learning in university education: Analyzing students' perspectives. Electronic Journal of e-Learning, 19(3), pp. 107-117. https://doi.org/10.34190/ejel.19.3.2168.

Albantani, A. M. and Madkur, A., 2017. Musyahadat al fidyu: YouTube-based teaching and learning of Arabic as foreign language (AFL). Dinamika Ilmu, 17(2), pp. 291-308.

Ali, W., 2020. Online and remote learning in higher education institutes: A necessity in light of COVID-19 pandemic. Higher Education Studies, 10(3), pp. 16-25.

Aljojo, N., Munshi, A., Almukadi, W., Alanaya, I., Zainol, A., Albalawi, H., Alharbi, G., Almadani, N., Almohammadi, E., Kadu, A., Abdulghaffar, N., Almohammadi, E., Kadu, A., Abdulghaffar, N., 2019. The design and implementation of an Arabic pronunciation application for early childhood. Journal of Technology and Science Education, 9(2), pp. 136152. http://dx.doi.org/10.3926/jotse.486.

Amin, H. and Mirza, M. S., 2020. Comparative study of knowledge and use of Bloom's digital taxonomy by teachers and students in virtual and conventional universities. Asian Association of Open Universities Journal, 15(2), pp. 223-238. doi: 10.1108/AAOUJ-01-2020-0005.

Apriyanti, D., Syarif , H., Ramadhan , S., Zaim, M., Agustina, A., 2019. Technology-based Google classroom in English business writing class. Proceedings of the Seventh International Conference on Languages and Arts (ICLA 2018). Advances in Social Science, Education and Humanities Research, 301, pp. 689-694. https://dx.doi.org/10.2991/icla18.2019.113.

Arvanitis, P., 2019. Self-paced language learning using online platforms. In: M. Dressman and R. W. Sadler, eds. 2020. The handbook of informal language learning. Hoboken: Wiley-Blackwell. pp. 117-138.

Asakereh, A. and Dehghannezhad, M., 2015. Student satisfaction with EFL speaking classes: Relating speaking self-efficacy and skills achievement. Issues in Educational Research, 25(4), pp. 345-363.

Bahruddin, U. and Febriani, S. R., 2020. Student's perceptions of Arabic online learning during COVID-19 emergency. Journal for the Education of Gifted Young Scientists, 8(4), pp. 1483-1492.

Bloom, B. S., 1956. Taxonomy of educational objectives: The classification of educational goals. London: Longman.

van Cappelle, Chopra, V., Ackers, J. and Gochyyev, P., 2021. An analysis of the reach and effectiveness of distance learning in India during school closures due to COVID-19. International Journal of Educational Development, 85, pp.1-10. https://doi.org/10.1016/j.ijedudev.2021.102439.

Coleman, D. W. and Yamazaki, K., 2018. Simulation. In: J. I. Liontas, ed. The TESOL encyclopedia of English language teaching. Hoboken: Wiley-Blackwell. pp. 1-7. 
Dehghanzadeh, H., Fardanesh, H., Hatami, J., Talaee, E. and Noroozi, O., 2019. Using gamification to support learning English as a second language: A systematic review. Computer Assisted Language Learning, 34(7), pp. 1-24. https://doi.org/10.1080/09588221.2019.1648298.

Dolog, P., Henze, N., Nejdl, W., and Sintek, M., 2004. Personalization in distributed e-learning environments. In: S. Feldman and M. Uretsky, Proc. Proceedings of the 13th international World Wide Web conference on alternate track papers \& posters. ACM, New York City, Mai: United States. pp. 170-179. Association for Computing Machinery. https://doi.org/10.1145/1013367.1013395.

Dörnyei, Z., 2007. Research methods in applied linguistics. Oxford: Oxford University Press.

Ertmer, Peggy A., and Ottenbreit-Leftwich, A., 2013. Removing obstacles to the pedagogical changes required by Jonassen's vision of authentic technology-enabled learning. Computers \& Education, 64, pp. 175-82.

Fathi, J., Mohammad Yousefi, L. and Sedighravesh, M., 2017. The impact of self-assessment and peer-assessment in writing on the self-regulated learning of Iranian EFL students. Journal of Sociological Research, 8(2), pp. 1-16.

Fauzi, M., Murdiono, M., Anindiati, I., Nada, A., Khakim, R., Mauludiyah, L. and Thoifah, I., 2020. Developing Arabic language instructional content in Canvas LMS for the era and post Covid-19 pandemic. Izdihar: Journal of Arabic Language Teaching, Linguistics, and Literature, 3(3), pp. 161-180. https://doi.org/10.22219/iiz.v3i3.15017.

Ferri, F., Grifoni, P. and Guzzo, T., 2020. Online learning and emergency remote teaching: Opportunities and challenges in emergency situations. Societies, 10(4), p. 86. https://doi.org/10.3390/soc10040086.

Flores, J. F. F., 2015. Using gamification to enhance second language learning. Digital Education Review, 27(21), pp. 32-54. https://doi.org/10.1344/der.2015.27.32-54.

Garrison, D. R. and Norman D. V., 2008. Blended learning in higher education: Framework, principles, and guidelines. New Jersey: John Wiley \& Sons.

Ghani, M. T. A. and Daud, W., 2018. Adaptation of ADDIE instructional model in developing educational website for language learning. Global Journal Al-Thaqafah, 8(2), pp. 7-16.

Grgurovic, M., 2011. Blended learning in an ESL class: A case study. Calico Journal, 29(1), pp. 100-117.

Guichon, N. and Cohen, C., 2016. Multimodality and CALL. In: F. Farr and L. Murray, eds. The Routledge Handbook of Language Learning and Technology. London: Routledge. pp. 509-521.

Haggag, H. M., 2019. Using Google classroom in enhancing communicative grammar use and attitudes of non-English specialized postgraduates. European Scientific Journal, 15(1), pp. 261-281. http://dx.doi.org/10.19044/esj.2019.v15n1p261.

Harasim, L., 2017. Learning theory and online technologies. London: Routledge.

Hornack, A. M., 2011. Technology integration matrix. Technology Integrated Teaching and Learning. [online] Available at: < http://teche.pbworks.com/f/hornackassignment4-4 22 2011.pdf $>$ [Accessed 22 December 2020].

Hussein Alsowayegh, N., Bardesi, H., Garba, I. and Sipra, M., 2019. Engaging students through blended learning activities to augment listening and speaking. Arab World English Journal (AWEJ) Special Issue on CALL, (5), pp. 267-288. https://dx.doi.org/10.24093/awej/call5

Islam, M. S., 2019. Bangladeshi university students' perceptions about using Google Classroom for teaching English. International Journal of Psycho-Educational Sciences,8(2), pp. 57-65.

Johnson, A. D., 2016. Designing 'authenticity' in digital learning environments. Journal of Interactive Technology and Pedagogy, Issue 9. [online] Available at: <https://jitp.commons.gc.cuny.edu/designing-authenticity-in-digitallearning-environments/ > [Accessed 8 March 2021].

Kučírková, L., Kučera, P. and Vydrová, H. V., 2014. English for specific purposes e-learning experimental research. Journal on Efficiency and Responsibility in Education and Science, 7(3-4), pp. 80-86. https://doi.org/10.7160/eriesj.2014.070306

Kukulska-Hulme, A., 2016. Personalization of language learning through mobile technologies. The Cambridge Papers in ELT Series, October 2016, pp. 3-20.

Lebedeva, M., 2018. Multimodality as a new literacy: Language learning in the age of multimodal semiotics. In: CROSSINTER-MULTI-TRANS, 13th World Congress of the International Association for Semiotic Studies (IASS/AIS), Kaunas, March 2018, pp. 381-387.

Liu, K.P., Tai, S.J. D. and Liu, C., 2018. Enhancing language learning through creation: The effect of digital storytelling on student learning motivation and performance in a school English course. Educational Technology Research and Development, 66(4), pp. 913-935. doi :10.1007/S11423-018-9592-Z.

van Merriënboer, J. and Paul A. K., 2017. Ten steps to complex learning: A systematic approach to four-component instructional design. London: Routledge.

Mohammed, T. A., Assam, B. N. and Saidi, M., 2020. The use of Web 2.0 tools in the foreign language classroom. Journal of Educational and Social Research, 10(2), pp. 177-190. https://doi.org/10.36941/jesr-2020-0037

Mohammed, T. A. S., 2018. Effectiveness of using Web 2.0 in developing language skills of Arabic as a second language. Journal of Linguistic and Literary Studies, 10(13), pp. 4-32.

Mohammed, T. A. S., Al-Sowaidi, B. and Banda, F., 2021. Towards a technology-enhanced blended approach for teaching Arabic for Shari'ah purposes (ASP) in the light of the South African National Qualifications Framework. International Journal of Information and Education Technology, 11(1), pp. 1-9. doi: 10.18178/ijiet.2021.11.1.1481.

Mpungose, C. B., 2020. Emergent transition from face-to-face to online learning in a South African university in the context of the Coronavirus pandemic. Humanities and Social Sciences Communications, 7(1), pp. 1-9.

https://doi.org/10.1057/s41599-020-00603-x 
Oğuz, A. and Bahar, H. O., 2008. The importance of using authentic materials in prospective foreign language teacher training. Pakistan Journal of Social Sciences, 5(4), pp. 328-336.

Osada, N., 2004. Listening comprehension research: A brief review of the past thirty years. Dialogue, 3 (1), pp. 53-66.

Picciano, A. G., 2017. Theories and frameworks for online education: Seeking an integrated model. Online Learning, 21 (3), pp.166-90. http://dx.doi.org/10.24059/olj.v21i3.1225

Pramila, K. and Thomas, J., 2019. Impact of blended learning on the speaking skills of English as a foreign language (EFL) learners at Sohar University, Sultanate of Oman. The Anthropologist, 35(1-3), pp. 47-56. doi: 10.31901/24566802.2019/35.1-3.2039.

Rabbi, M. M. F., Zakaria, A. K. M. and Tonmoy, M., 2017. Teaching listening skill through Google Classroom: A study at tertiary level in Bangladesh. DUET Journal, 3(10), pp. 103-108.

Rahmawati, F., 2019. Blended learning in an English listening and speaking course: Freshmen's voice and choice. In: Third International Conference on Sustainable Innovation 2019-Humanity, Education and Social Sciences (ICOSIHESS 2019). Dordrecht: Atlantis Press. doi: $10.2991 /$ icosihess-19.2019.9

Rao, P. S., 2019. The effective use of authentic materials in the English language classrooms. Humanities, 7(1), pp. 1-8. https://doi.org/10.34293/sijash.v7i1.556

Rapanta, C., Botturi, L., Goodyear, P., Guardia, L. and Koole, M., 2020. Online university teaching during and after the COVID-19 crisis: Refocusing teacher presence and learning activity. Postdigital Science and Education, 2(3), pp. 923945. https://doi.org/10.1007/s42438-020-00155-y

Robin, B. R., 2008. Digital storytelling: A powerful technology tool for the 21st century classroom. Theory Into Practice, 47(3), pp. 220-228.

Rymanova, I., Baryshnikov, N. and Grishaeva, A., 2015. E-course based on the LMS Moodle for English language teaching: Development and implementation of results. Procedia-Social and Behavioral Sciences, 206, pp. 236-240. https://doi.org/10.1016/J.SBSPRO.2015.10.016

Scrivener, J., 2005. Learning teaching. Vol. 2. Oxford: Macmillan.

Shalihah, S., Zubaidah, kardena, A., Hodijah, O., Afrida, Y., and Safitri, L., 2021. Web-based e-learning application for learning Arabic language. Journal of Physics: Conference Series. IOP Publishing, pp.1-9. doi: 10.1088/1742$6596 / 1779 / 1 / 012011$

Spiller, D., 2012. Assessment matters: Self-assessment and peer assessment. Hamilton, New Zealand: The University of Waikato.

Technology Integration Matrix. 2009. A video resource supporting the full integration of technology in Florida schools. [online] Available at: <https://fcit.usf.edu/matrix/ > [Accessed 12 August 2020].

Toney, S., Light, J. and Urbaczewski, A., 2021. Fighting Zoom fatigue: Keeping the zoombies at bay. Communications of the Association for Information Systems, 48(1), p. 10. doi: 10.17705/1CAIS.04806

Touchie, H. Y., 1986. Second language learning errors: Their types, causes, and treatment. JALT Journal, 8(1), pp. 75-80.

Tullis, J. G. and Benjamin, A. S., 2011. On the effectiveness of self-paced learning. Journal of Memory and Language, 64(2), pp. 109-118. https://dx.doi.org/10.1016\%2Fj.jml.2010.11.002

Tumskiy, S., 2019. The use of learning management systems in the teaching of English to high-level learners at tertiary level. In: INTED2019, 13th International Technology, Education and Development Conference. Valencia, Spain, 11-13 March, 2019, pp. 3530-3535. http://dx.doi.org/10.21125/inted.2019.0915

Udjaja, Y., 2018. Gamification assisted language learning for Japanese language using expert point cloud recognizer. International Journal of Computer Games Technology, 2018. doi: https://doi.org/10.1155/2018/9085179.

Walker, N., 2014. Listening: The most difficult skill to teach. Encuentro, 23, pp. 167-175.

Wang, Y. H., 2017. Integrating self-paced mobile learning into language instruction: Impact on reading comprehension and learner satisfaction. Interactive Learning Environments, 25(3), pp. 397-411. http://dx.doi.org/10.1080/10494820.2015.1131170.

Wargadinata, W., Maimunah, I., Febriani, S., and Humaira, L., 2020. Mediated Arabic language learning for Arabic students of higher education in COVID-19 situation. Izdihar: Journal of Arabic Language Teaching, Linguistics, and Literature, 3(1), pp. 1-18. https://doi.org/10.22219/jiz.v3i1.11862

Welsh, J., Harmes, J. C. and Winkelman, R., 2011. Florida's technology integration matrix. Principal Leadership, 12(2), pp. 69-71.

Winkelman, R., 2019. The invisible technology integration matrix, TIM. [online] The University of South Florida. Available at: <https://fcit.usf.edu/matrix/the-invisible-technology-integration-matrix/ > [Accessed 11 December 2020].

Winkelman, R., 2020. Bloom's cognitive taxonomy and the technology integration matrix, TIM. [online] The University of South Florida. Available at: < https://fcit.usf.edu/matrix/blooms-cognitive-taxonomy-and-the-technology-integrationmatrix/> [Accessed 11 December 2020].

Yugandhar, K., 2016. Interlacing Bloom's taxonomy and e-learning to improve the quality of English class. International Journal on Studies in English Language and Literature, 4(1), pp. 12-16.

Zainuddin, N. and Sahrir, M. S., 2016. Multimedia courseware for teaching Arabic vocabulary: Let's learn from the experts. Universal Journal of Educational Research, 4(5), pp. 1167-1172. http://dx.doi.org/10.13189/ujer.2016.040529. 